\title{
The carcinogenicity debate on formaldehyde: How to derive safe exposure limits?
}

\author{
Hermann M. Bolt · Gisela H. Degen · Jan G. Hengstler
}

Published online: 18 May 2010

(C) Springer-Verlag 2010

Matters of good epidemiological practice (Boffetta et al. 2008; Clapp and Kriebel 2009; McLaughlin et al. 2009; Cogliano and Straif 2010) and consequences of potential conflicts of interest (Boffetta et al. 2009; Hauptmann and Ronckers 2009) have been topics of recent editorials and correspondence in scientific journals publishing human toxicity studies, including Archives of Toxicology (Slama 2009; Slama et al. 2009; Morfeld 2009a, b, c). This discussion specifically affected evaluations of a number of industrially or environmentally important chemicals, such as acrylonitrile, TCDD (Boffetta et al. 2008) and formaldehyde (Boffetta et al. 2009; Hauptmann and Ronckers 2009; McLaughlin et al. 2009). In this context, also the current evaluation of formaldehyde by the International Agency for Research on Cancer (IARC (International Agency for Research on Cancer) 2006; Baan et al. 2009), indicating strong evidence related to human sino-nasal cancer and moderate evidence of human leukaemia, was questioned (McLaughlin et al. 2009).

Key topics of the toxicity and carcinogenicity of formaldehyde have been recently reviewed (Kupczewska-Dobecka 2007; Sul et al. 2007; Duhayon et al. 2008). The carcinogenicity of formaldehyde and the derivation of a safe occupational exposure limit have been matters of

H. M. Bolt $(\bowtie) \cdot$ G. H. Degen · J. G. Hengstler

Leibniz Institut für Arbeitsforschung an der TU Dortmund,

Leibniz Research Centre for Working Environment

and Human Factors (IfADo), Ardeystrasse 67,

44139 Dortmund, Germany

e-mail: bolt@ifado.de documentations by a number of scientific expert panels, including DFG (Deutsche Forschungsgemeinschaft) (2000), DECOS (Health Council of the Netherlands: Dutch Expert Committee on Occupational Standards) (2003), Nordic Expert Group (2003) and SCOEL (Scientific Committee on Occupational Exposure Limits) (2008). Just recently, SCOEL (Scientific Committee on Occupational Exposure Limits) (2008) has considered formaldehyde to be a "genotoxic carcinogen, for which a practical threshold is supported" (category 3, according to Bolt and HuiciMontagud 2008) and has recommended a health-based Occupational Exposure Limit of $0.2 \mathrm{ppm}$.

By contrast to occupational exposure, scientifically based recommendations for a health-based limit of environmental formaldehyde exposure, especially for indoor air exposure, have been scarce. For many chemicals, recommendations of safe environmental exposure levels were traditionally based on dividing recommended occupational limits by a fixed factor, e.g. a factor of 100 . For formaldehyde, the German Umweltbundesamt had issued a specific recommendation of an indoor air limit for formaldehyde of $0.1 \mathrm{ppm}$ and confirmed this in 2006 (UBA (Umweltbundesamt) 2006). However, an updated extensive documentation has been lacking.

In this issue of Archives of Toxicology, Nielsen and Wolkoff (2010) provide a new documentation on cancer effects of formaldehyde, in order to propose an indoor guideline level. They conclude that the guideline value of WHO (World Health Organization) (2000) of $0.08 \mathrm{ppm}$ formaldehyde is still preventive of carcinogenic effects, in compliance with recent epidemiological findings.

We hope that this publication will contribute to the present international discourse on how to amalgamate scientific toxicological findings with regulatory requirements. 


\section{References}

Baan R, Grosse Y, Straif K, Secretan B, El Ghissassi F, Bouvard V, Benbrahim-Tallaa L, Guha N, Freeman C, Galichet L, Cogliano $\mathrm{V}$ (2009) A review of human carcinogens-part F: chemical agents and related occupations. Lancet Oncol 10:1143-1144

Boffetta P, McLaughlin JK, La Vecchia C, Tarone RE, Lipworth L, Blot J (2008) False-positive results in cancer epidemiology: a plea for epistemological modesty. J Natl Cancer Inst 100:988-995

Boffetta P, McLaughlin JK, La Vecchia C, Tarone RE, Lipworth L, Blot WJ (2009) A further plea for adherence to the principles underlying science and the epidemiological enterprise in particular. Int J Epidemiol 38:678-679

Bolt HM, Huici-Montagud A (2008) Strategy of the Scientific Committee on Occupational Exposure Limits (SCOEL) in the derivation of occupational exposure limits for carcinogens and mutagens. Arch Toxicol 82:61-64

Clapp RW, Kriebel D (2009) Re: False-positive results in cancer epidemiology: a plea for epistemological modesty. J Natl Cancer Inst 101:211-212 author reply 213-214

Cogliano V, Straif K (2010) Re: false-positive results in cancer epidemiology: a plea for epistemological modesty. J Natl Cancer Inst 102:134

DECOS (Health Council of the Netherlands: Dutch Expert Committee on Occupational Standards) (2003) Formaldehyde. Health-based recommended occupational exposure limit. The Hague, Health Council of the Netherlands. Publication no. 2003/02OSH

DFG (Deutsche Forschungsgemeinschaft) (2000) Formaldehyde. In: Occupational toxicants, vol 17. VCH-Wiley, Weinheim/ Germany, pp 163-201

Duhayon S, Hoet P, Van Maele-Fabry G, Lison D (2008) Carcinogenic potential of formaldehyde in occupational settings: a critical assessment and possible impact on occupational exposure levels. Int Arch Occup Environ Health 81:695-710

Hauptmann M, Ronckers CM (2009) Re: a further plea for adherence to the principles underlying science and the epidemiological enterprise in particular. Int J Epidemiol [Epub ahead of print Dec 21, 2009]; author reply [Epub ahead of print Dec 21, 2009]

IARC (International Agency for Research on Cancer) (2006) Formaldehyde, 2-butoxyethanol and 1-tert-butoxypropan-2-ol. IARC Monogr Eval Carcinog Risks Hum 88:1-478

Kupczewska-Dobecka M (2007) Assessment of carcinogenicity of formaldehyde based on the newest literature data. Med $\mathrm{Pr}$ 58:527-539
McLaughlin JK, La Vecchia C, Tarone RE, Lipworth L, Blot WJ (2009) Response. J Natl Cancer Inst [Epub ahead of print Dec 9, 2009]

Morfeld P (2009a) A plea for rigorous and honest science: false positive findings and biased presentations in epidemiological studies. Arch Toxicol 83:105-106

Morfeld P (2009b) Comment on Slama R, Cyrys J, Herbarth O, Wichmann HE, Heinrich J (2009) A further plea for rigorous science and explicit disclosure of potential conflicts of interest. Arch Toxicol 83: 517-518

Morfeld P (2009c) Comment on Slama R, Cyrys J, Herbarth O, Wiechmann HE, Heinrich J saying "The authors did not wish to reply, given Dr. Morfeld's persistence in refusing to fill in the conflict of interest statement an in misleadingly quoting parts of the sentences of our publications". Arch Toxicol 83: 645-646

Nielsen GD, Wolkoff P (2010) Cancer effects of formaldehyde: a proposal for an indoor air guideline value. Arch Toxicol 84 (this issue)

Nordic Expert Group (2003) The Nordic expert group for criteria documentation of health risks from chemicals and the dutch committee on occupational standards. 132. Formaldehyde. Arbete och Hälsa, Vetenskaplig Skriftserie No. 11:2003, Stockholm

SCOEL (Scientific Committee on Occupational Exposure Limits) (2008) Recommendation from the Scientific Committee on Occupational Exposure Limits for formaldehyde 50-00-0. European Union. Online available via: http://ec.europa.eu/social/ keyDocuments.jsp?type $=0 \&$ policy Area $=82 \&$ subCategory $=153$ $\&$ country $=0 \&$ year $=0 \& \operatorname{advSearchKey}=$ recommendation $\&$ mode $=$ advancedSubmit\&langId=en. Accessed 7 May 2010

Slama R (2009) Letter to the editor. Arch Toxicol 83:515

Slama R, Cyrys J, Herbarth O, Wichmann HE, Heinrich J (2009) A further plea for rigorous science and explicit disclosure of potential conflicts of interest. Arch Toxicol 83:293-295

Sul D, Kim H, Phark S, Cho E, Choi S, Kang HS, Kim EM, Hwang KW, Jung WW (2007) Gene expression profiling in lung tissues from rats exposed to formaldehyde. Arch Toxicol 81:589-597

UBA (Umweltbundesamt) (2006) Empfehlung des Umweltbundesamtes. Krebserzeugende Wirkung von Formaldehyd-Änderung des Richtwertes für Innenraumluft von $0,1 \mathrm{ppm}$ nicht erforderlich. Bundesgesundheitsblatt-Gesundheitsforschung-Gesundheitsschutz 49:1169

WHO (World Health Organization) (2000) Air quality guidelines for Europe, 2nd edn. World Health Organization, Regional Office for Europe, Copenhagen, pp 87-91 